University of Nebraska - Lincoln

DigitalCommons@University of Nebraska - Lincoln

Faculty Publications, Department of Psychology

Psychology, Department of

January 1968

\title{
Rated Pleasantness and Association Value of 101 English Nouns
}

Albert Silverstein

University of Rhode Island,

Richard A. Dienstbier

University of Nebraska-Lincoln, rdienstbier2@unl.edu

Follow this and additional works at: https://digitalcommons.unl.edu/psychfacpub

Part of the Psychiatry and Psychology Commons

Silverstein, Albert and Dienstbier, Richard A., "Rated Pleasantness and Association Value of 101 English Nouns" (1968). Faculty Publications, Department of Psychology. 222.

https://digitalcommons.unl.edu/psychfacpub/222

This Article is brought to you for free and open access by the Psychology, Department of at DigitalCommons@University of Nebraska - Lincoln. It has been accepted for inclusion in Faculty Publications, Department of Psychology by an authorized administrator of DigitalCommons@University of Nebraska - Lincoln. 


\title{
Rated Pleasantness and Association Value of 101 English Nouns ${ }^{1}$
}

\author{
Albert Silverstein and Richard A. Dienstbier \\ University of Rhode Island, Kingston, Rhode Island 02881
}

Ratings of pleasantness (PL) on a 7-point scale and of association value ( $\left.\mathrm{a}^{\prime}\right)$ on a 5-point scale are reported for 101 two-syllable nouns. The ratings were obtained from two samples of 100 women each and two samples of 100 men each. Sizable differences were obtained between words on both scales. For women and men respectively, PL and $\mathrm{a}^{\prime}$ were correlated .570 and .585 ; PL and printed frequency were correlated .233 and .207 ; frequency and a' were correlated .533 and .764. Women's and men's ratings correlated .973 for PL and .899 for $\mathrm{a}^{\prime}$.

Despite the challenging papers of Johnson, Frincke, and Martin, and Johnson, Thomson, and Frincke (1960, 1961), very little recent work has been reported on the influence of pleasantness of materials on recognition or verbal learning. Perhaps this is due partly to an absence of a standardized set of pleasantness norms for a large sample of verbal materials. The items presented by Johnson et al. do not constitute a sample large enough to allow investigators much choice. The emotionality ratings of dissyllables reported by Noble (1958) are not based upon a sufficiently continuous scale; his $S$ s could respond only "pleasant," "neutral," or "unpleasant." The few recent studies of the relation between affect and verbal learning have used nonsense syllables, and Keppel's study (1963) has been criticized for not employing a wide enough range of affective variation (Silverstein and McCreary, 1964). The latter authors used nonsense syllables also, but in this case the differences in pleasantness were experimentally manipulated. In an effort to fill this obvious gap, the present paper reports rated pleasantness values for 101 two-syllable nouns. Rated association values also were obtained for these words. Since meaningfulness is such a potent determiner of learning speed, it is important that investigators be able to select various combinations of pleasantness and meaningfulness of words to be used. In addition, further information on the correlation between meaningfulness and pleasantness could be obtained.

\section{Method}

Ninety-five of the words presented here were obtained by randomly selecting two-syllable nouns from the Thorndike and Lorge Teacher's Wordbook (1944). Six of the words were added to increase the affective range. The words were rated for association value $\left(\mathrm{a}^{\prime}\right)$ by 100 male and 100 female students at the University of Rhode Island, and by different samples of 100 men and 100 women students for pleasantness (PL). The instructions used for the a' ratings were very similar to those used by Noble (e.g., 1961) except that the example words used were "Green" and "Glonoin." The Ss rated how many associations each word gave them by checking one of the following categories: (a) none, (b) below average, (c) average, (d) above average, and (e) very many. They were not allowed to go back to change any of their ratings.

The $S$ s used a thermometer-type scale to rate the subjective pleasantness of the words (Guilford, 1954). The categories are: (a) very unpleasant, (b) moderately unpleasant, (c) slightly unpleasant, (d) neutral, (e) slightly pleasant, (f) moderately pleasant, and (g) very pleasant. The $S$ s were instructed to treat the categories as equally spaced and to judge each word independently of their previous

\footnotetext{
${ }^{1}$ This research was supported by grant MH 08974 from the National Institute of Mental Health, U.S. Public Health Service.
} 
TABLE I

Mean Ratings of Association Value, Pleasantness and Lorge Frequency-Counts for 101 English Nouns

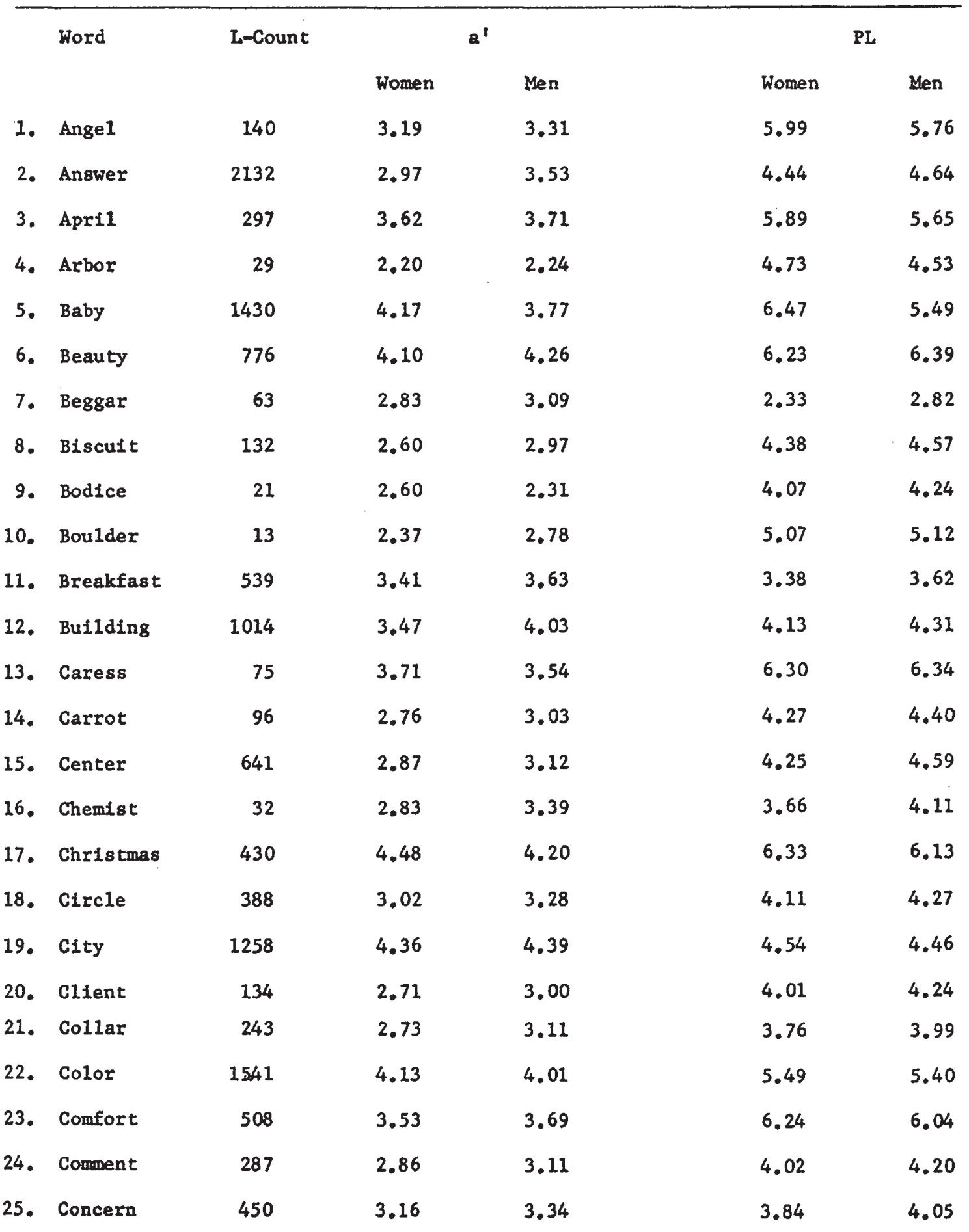


TABLE 1

continued

\begin{tabular}{|c|c|c|c|c|c|c|}
\hline \multirow{2}{*}{\multicolumn{2}{|c|}{ Word }} & \multirow[t]{2}{*}{ L-Count } & \multicolumn{2}{|c|}{$a^{\prime}$} & \multicolumn{2}{|c|}{ PL } \\
\hline & & & Women & Men & Women & Men \\
\hline 26. & Corner & 899 & 2.73 & 3.03 & 3.49 & 3.77 \\
\hline 27. & Cotton & 577 & 3.33 & 3.17 & 4.56 & 4.64 \\
\hline 28. & Country & 1714 & 4.07 & 4.04 & 5.84 & 5.68 \\
\hline 29. & Courage & 349 & 3.32 & 3.77 & 5.77 & 5.83 \\
\hline 30. & Dancer & 87 & 3.52 & 3.39 & 5.52 & 5.46 \\
\hline 31. & Defect & 47 & 2.81 & 3.07 & 2.36 & 2.85 \\
\hline 32. & Delight & 353 & 3.73 & 3.53 & 6.34 & 6.03 \\
\hline 33. & Device & 144 & 2.66 & 3.27 & 3.89 & 4.43 \\
\hline 34. & Dinner & 1266 & 3.71 & 3.60 & 5.62 & 5.57 \\
\hline 35. & Discord & 14 & 2.36 & 2.31 & 2.45 & 3.01 \\
\hline 36. & Divorce & 312 & 3.09 & 3.02 & 1.46 & 2.11 \\
\hline 37. & Emerald & 61 & 3.11 & 2.95 & 5.84 & 5.38 \\
\hline 38. & Evening & 2087 & 4.08 & 3.89 & 6.13 & 5.73 \\
\hline 39. & Family & 1976 & 4.44 & 4.23 & 6.36 & 5.66 \\
\hline 40. & Figure & 1202 & 3.54 & 3.84 & 4.55 & 5.20 \\
\hline 41. & Flower & 902 & 4.13 & 4.04 & 6.34 & 5.69 \\
\hline 42. & Fragrance & 70 & 3.48 & 3.29 & 5.99 & 5.40 \\
\hline 43. & Garden & 1036 & 3.89 & 3.61 & 5.82 & 5.04 \\
\hline 44. & Grocer & 31 & 3.19 & 3.39 & 4.17 & 4.39 \\
\hline 45. & Habit & 462 & 3.09 & 3.29 & 3.41 & 3.70 \\
\hline 46. & Hunger & 93 & 3.29 & 3.44 & 2.12 & 2.60 \\
\hline 47. & Hus band & 1788 & 4.27 & 4.20 & 6.41 & 5.68 \\
\hline 48. & Insect & 91 & 3.47 & 3.58 & 2.37 & 2.85 \\
\hline 49. & Ivory & 91 & 2.77 & 3.04 & 5.75 & 5.41 \\
\hline 50. & Jewe 1 & 150 & 3.69 & 3.55 & 5.78 & 5.49 \\
\hline 51. & Justice & 181 & 3.23 & 3.57 & 5.88 & 5.23 \\
\hline 52. & Kindness & 115 & 3.71 & 3.31 & 6.37 & 6.20 \\
\hline 53. & Lotion & 30 & 2.87 & 2.66 & 5.06 & 4.84 \\
\hline
\end{tabular}


TABLE 1

continued

\begin{tabular}{|c|c|c|c|c|c|c|}
\hline \multirow{2}{*}{\multicolumn{2}{|c|}{ Word }} & \multirow[t]{2}{*}{$I$-Count } & \multicolumn{2}{|c|}{$a^{\prime}$} & \multicolumn{2}{|c|}{ PL } \\
\hline & & & Women & Men & Women & Men \\
\hline 54. & Mallet & 17 & 2.21 & 2.44 & 3.36 & 3.76 \\
\hline 55. & Model & 244 & 3.31 & 3.46 & 4.69 & 5.05 \\
\hline 56. & Moment & 2396 & 2.79 & 3.20 & 4.54 & 4.34 \\
\hline 57. & Morning & 2015 & 3.74 & 3.87 & 5.22 & 5.17 \\
\hline 58. & Mother & 3993 & 4.36 & 4.27 & 6.20 & 5.93 \\
\hline 59. & Mountain & 288 & 3.62 & 3.84 & 5.53 & 5.64 \\
\hline 60. & Music & 660 & 4.21 & 3.99 & 6.26 & 5.96 \\
\hline 61. & object & 394 & 3.33 & 3.49 & 3.85 & 4.06 \\
\hline 62. & Office & 1640 & 3.67 & 3.54 & 3.79 & 4.13 \\
\hline 63. & Ordeal & 57 & 2.86 & 3.01 & 2.18 & 2.70 \\
\hline 64. & Oven & 326 & 3.20 & 3.10 & 4.26 & 4.11 \\
\hline 6.5 . & Panel & 102 & 2.70 & 2.94 & 3.89 & 4.09 \\
\hline 66. & Paper & 1235 & 3.40 & 3.81 & 4.03 & 4.06 \\
\hline 67. & Partner & 225 & 3.40 & 3.53 & 5.38 & 5.51 \\
\hline 68. & Party & 1442 & 4.16 & 4.21 & 5.85 & 5.91 \\
\hline 69. & Passage & 171 & 2.73 & 3.01 & 4.28 & 4.41 \\
\hline 70. & Patriot & 11 & 2.93 & 3.27 & 5.28 & 5.54 \\
\hline 71. & Pencil & 186 & 3.09 & 3.32 & 3.98 & 4.17 \\
\hline 72. & People & 3574 & 4.45 & 4.49 & 5.81 & 5.23 \\
\hline 73. & Perfume & 150 & 3.52 & 3.43 & 5.84 & 5.60 \\
\hline 74. & Pleasure & 442 & 4.04 & 4.10 & 6.31 & 6.43 \\
\hline 75. & Progress & 365 & 3.27 & 3.43 & 5.61 & 5.50 \\
\hline 76. & Quota & 29 & 2.77 & 3.04 & 3.60 & 3.86 \\
\hline 77. & Scanda1 & 99 & 3.10 & 3.00 & 1.77 & 2.47 \\
\hline 78. & Shadow & 491 & 2.91 & 3.08 & 3.94 & 4.15 \\
\hline 79. & Shoulder & 1135 & 2.75 & 3.03 & 4.75 & 4.79 \\
\hline 80. & silence & 714 & 2.88 & 3.13 & 4.81 & 4.84 \\
\hline 81. & Slipper & 148 & 2.78 & 3.05 & 4.77 & 4.82 \\
\hline
\end{tabular}


TABLE 1

continued

\begin{tabular}{|c|c|c|c|c|c|c|}
\hline \multirow{2}{*}{\multicolumn{2}{|c|}{ Word }} & \multirow[t]{2}{*}{ L-Count } & \multicolumn{2}{|c|}{$a^{\prime}$} & \multicolumn{2}{|c|}{ PL } \\
\hline & & & Women & Men & Women & Men \\
\hline 82. & Statue & 58 & 2.92 & 2.94 & 4.49 & 4.56 \\
\hline 83. & Study & 942 & 3.98 & 3.97 & 3.57 & 3.83 \\
\hline 84. & Success & 573 & 3.69 & 4.09 & 6.14 & 6.16 \\
\hline 85. & Summer & 783 & 4.64 & 4.46 & 6.55 & 6.30 \\
\hline 86. & Sunday & 529 & 3.88 & 3.84 & 5.42 & 5.34 \\
\hline 87. & Sunshine & 194 & 3.93 & 3.80 & 6.41 & 6.21 \\
\hline 88. & Swee theart & 157 & 4.22 & 3.91 & 6.54 & 6.19 \\
\hline 89. & Table & 1325 & 3.31 & 3.57 & 4.12 & 4.04 \\
\hline 90. & Toddler & 3 & 3.82 & 3.36 & 6.11 & 5.52 \\
\hline 91. & Tower & 201 & 2.86 & 3.31 & 4.54 & 4.56 \\
\hline 92. & Trouble & 1180 & 3.56 & 3.86 & 1.73 & 2.44 \\
\hline 93. & Valley & 289 & 3.13 & 3.32 & 5.44 & 5.35 \\
\hline 94. & Wafer & 16 & 2.33 & 2.53 & 4.38 & 4.20 \\
\hline 95. & Wagon & 325 & 3.01 & 3.10 & 4.13 & 4.04 \\
\hline 96. & Water & 2067 & 3.88 & 4.00 & 5.47 & 5.42 \\
\hline 97. & Window & 1564 & 3.16 & 3.50 & 4.76 & 4.74 \\
\hline 98. & Wisdom & 139 & 3.31 & 3.57 & 6.17 & 5.94 \\
\hline 99. & Woman & 2431 & 4.29 & 4.44 & 5.20 & 6.37 \\
\hline 100. & Worker & 429 & 3.53 & 3.68 & 4.27 & 4.20 \\
\hline 101. & Zenith & 2 & 2.40 & 2.72 & 4.87 & 4.94 \\
\hline
\end{tabular}

ratings. As in the a' ratings $S$ s were told to silently pronounce each word first.

The procedures were the same for both sets of ratings. Groups of 12-20 Ss rated the words. Total time per session was between 20 and $25 \mathrm{~min}$. The $S$ s were allowed to work at their own pace, but were urged to work quickly. Seven different random orders of presentation of words were used for each of the ratings, with the restriction that no word appear in the first or last ten in more than one order. Each word was dittoed on a separate page, and the total list was presented to $S$ s in booklets of 20 . The $S$ s were instructed to take a few seconds' rest after completing each booklet.

\section{Results}

Table I presents the means of the men's and women's a' and PL ratings for each word, along with its Thorndike-Lorge frequency. Higher values represent greater degrees of pleasantness and meaningfulness. A large degree of variation among words was found for both rated dimensions. The variabilities of the ratings from one word to the next did not differ greatly. For both men and women, 88 of the words' PL ratings had $S D$ values ranging from 0.79 to 1.39 . The largest $S D$ was 1.73 and the 
median was 1.23 . For the a ratings, 99 of the words had $S D$ s of between 0.67 and 1.08. The largest $S D$ was 1.29 , and the median was 0.93 . Overall reliability of the ratings was fairly high. Split-half reliability coefficients were .861 and .854 for $\mathrm{a}^{\prime}$, and .818 and .886 for PL, with women and men, respectively.

The three variables were found to be reliably correlated with each other. PL and $\mathrm{a}^{\prime}$ showed product-moment correlation coefficients of $.570(p<.01)$ for the women and .585 $(p<.01)$ for the men. PL and Lorge Count were correlated $.233(p<.025)$ for the women and $.207(p<.025)$ for the men. Lorge Count was correlated with $\mathrm{a}^{\prime} .533(p<.01)$ for the women and $.764(p<.01)$ for the men. The correlations presented by Johnson et al. (1960) between pleasantness and frequency were .38 , .40 , and .63; roughly the same order of magnitude as that presented here. That the correlation between $\mathrm{a}^{\prime}$ and frequency fell so far short of unity is to be expected from Noble's (1963) discussion of this relation. Despite the fact that scatterplots of the relation between PL and $\mathrm{a}^{\prime}$ showed a tendency for very unpleasant words to be given higher a' values than neutral words, correlations between $a^{\prime}$ and distance from affective neutrality failed to increase the values of $r$ more than .02 above those obtained for $\mathrm{a}^{\prime}$ and PL. These values are in close approximation to the correlation obtained by Noble (1958) between emotionality and meaningfulness (defined by the production method). These correlations make it clear that independent manipulation of words' pleasantness and meaningfulness is not easily accomplished.

The ratings given by the men and women were correlated .973 for PL and .899 for $\mathrm{a}^{\prime}$.
These values are slightly higher than the reliability coefficients obtained and indicate that there is great interchangeability possible in items used for men and women college students.

\section{REFERENCES}

Guilford, J. P. Psychometric methods (2nd Ed.) New York: McGraw-Hill, 1954

Johnson, R. C., Frincke, G., and Martin, L. Meaningfulness, frequency and affective character or words as related to visual duration threshold. Canad. J. Psychol., 1961, 15, 199-204.

Johnson, R. C., Thomson, C. W., and Frincke, G. Word values, word frequency and visual duration threshold. Psychol. Rev., 1960, 67, 332342.

Keppel, G. Word value and verbal learning. J. verb. Learn. verb. Behav., 1963, 1, 353-356.

Noble, C. E. Emotionality (e) and meaningfulness (m), Psychol. Rep., 1958, 4, 16.

Noble, C. E. Meaningfulness and familiarity. In Cofer, C. N. (Ed.), Verbal behavior and learning: problems and processes. New York: McGraw-Hill, 1963.

Noble, C. E. Measurements of association value (a), rated association value $\left(\mathrm{a}^{\prime}\right)$ and scaled meaningfulness $\left(\mathrm{m}^{\prime}\right)$ for the $2100 \mathrm{CVC}$ combinations of the English alphabet. Psychol. Rep., 1961, 8, 487-521. (Monogr. Suppl. 3-v8).

Silverstein, A., and Mccreary, C. Acquired word value and verbal learning. Psychol. Rep., 1964,14, 499-504.

Thorndike, E. L., and Lorge, I. The teacher's word book of 30,000 words. New York: Teachers College, Columbia Univ. Press, 1944.

Submitted July 1966 